This is a preprint version of the article published in Population, Space and Place:

Hercog, M, Cangià, F. Skills on the move: Highly skilled migrants in Switzerland and beyond. Popul Space Place. 2021;e2457. https://doi.org/10.1002/psp.2457

\title{
Skills on the Move: Highly Skilled Migrants in Switzerland and Beyond \\ Metka Hercog
}

Institute of Cultural Anthropology and European Ethnology, NCCR-on the move, University of Basel, Basel, Switzerland

Flavia Cangia

NCCR-on the move/NCCR LIVES, University of Fribourg, Fribourg, Switzerland

\begin{abstract}
This article explores how highly skilled migrants make sense of and subjectively validate their skills when in search of employment in a new country. Using a transnational perspective, we suggest that in the context of migration, skills can only be properly understood if we consider the multiple locations and events in people's life trajectories. In addition to foregrounding the spatial context, we also explore skills through a temporal perspective. The country of origin, previous countries of migration, receiving context and future destinations, as well as past experiences and future plans can all play a role in the way individuals make sense of and subjectively validate what migrants themselves consider to be their skills. Drawing upon qualitative research among highly skilled migrants in Switzerland, we examine how personal and professional skills intertwine with each other when people engage with a given yet evolving socioeconomic environment.
\end{abstract}

Keywords: skilled migration, migration, mobility, career trajectories, skills transfer, Switzerland 


\section{Introduction: Skills and Migration}

'Skill' is a complex construct, influenced by power relations and social structures (Rigby \& Sanchis, 2006). For migrants, determining what counts as 'skill' is particularly challenging, especially when a person needs to make sense of, validate, and at times reshape personal and professional competences in a new environment. That migrants' formal education alone does not secure employment is clear from numerous studies on migrants' over-qualification and deskilling (Ariss \& Syed, 2011; Bauder, 2003; Burrell, 2010; Dustmann \& Frattini, 2013; McDowell, 2009; Nowotny, 2016; Waters, 2009). The validation of skills in a new context depends on more than just an identifiable set of skills (Aure, 2013; Beaverstock \& Boardwell, 2000; Bjerregaard, 2014; Raghuram, 2004). Personal social networks, support of public institutions and employers, as well as personal and social characteristics, such as ethnicity, race or age may affect the way skills are valued (by oneself and others) and how migrants access employment opportunities (Friberg \& Midtbøen, 2017; Sandoz, 2018; van den Broek et al., 2015).

Labour market trajectories are the most commonly discussed topic within skilled migration since any kind of deskilling is seen as a concern from the perspective of receiving countries as well as for the migrants (Aure, 2013; Landolt \& Thieme, 2018; Liversage, 2009; Riaño \& Baghdadi, 2007; Riano, Limacher, Aschwanden, Hirsig, \& Wastl-Walter, 2015; Winterheller \& Hirt, 2017). Some studies have also started to observe everyday place-making practices of skilled migrants, and focus on the importance of place and belonging in the international validation and transfer of skills (Cederberg, 2017; Conradson \& Latham, 2005; Föbker et al., 2016; Nowicka, 2014; Plöger \& Becker, 2015; Shinozaki, 2014; van Riemsdijk, 2014). These studies mostly view skills as context- 
specific in terms of integration to the receiving country. Further to that, Nowicka (2014) suggests that the context of migrants' origin is just as important for skills validation as the place of destination.

This article contributes to this body of research by focusing on the way migrants make sense of and subjectively validate their skills when in search of employment in a new country. We draw on qualitative research conducted since 2015 in Switzerland on highly skilled migrants and their families. In particular, we explore the experiences of highly skilled people who follow their partners for a new assignment to a new country and for this reason quit their previous job ${ }^{1}$, as well as highly skilled refugees. A focus on these people and their experiences would shed light on the challenges and uncertainties of highly skilled migration, too often associated with the image of 'privileged' and 'frictionless' forms of migration (Cangià \& Zittoun, 2018; Hercog \& Sandoz, 2018b). We propose to explore highly skilled migration from the perspective of migrants, including those who have experienced different kinds of skills mismatch, and to explore 'skills' also through a temporal perspective (Griffiths et al., 2013). Following the transnational and mobility turn in migration studies, we suggest that skills in the context of migration can only be properly understood when we consider the relevance of multiple locations and moments in people's mobile trajectories. Migration is viewed as a type of mobility (which can take many forms including tourism, daily commuting, educational mobility, just to name a few), as a spatial and temporal movement across multiple social and geographical contexts, involving pre-migration and post-migration mobilities (Dahinden, 2010). How do people understand and validate skills while

\footnotetext{
${ }^{1}$ We address them here as "accompanying partners". These people are also known in the literature as "trailing spouses" (Cangià, 2018), "secondary movers" (Tissot, 2016) or "tied migrants" (Ledin et al., 2007).
} 
making sense of themselves and their working life? We observe the subjective validation of skills through migration in a double sense, as a form of "practical knowledge" based on the specific position that one holds in a specific environment and moment of life; and as a form of "knowledge practice" through which a person constructs knowledge about oneself, portrays a possible future, and makes sense of change. Our findings show that these people create a transnational skill set with a particular quality of "throwntogetherness" (Massey, 2005), through which various trajectories and experiences distinct at the spatial and temporal level get 'thrown together' and interact: countries of origin, previous countries of migration, present receiving contexts and imagined future destinations, as well as past experiences and future plans all play a role in the way these people make sense of their life and work trajectories, and validate their skills into a new skill set.

In what follows, first, we present our conceptual framework. After introducing our study and fieldwork, we describe the context of Switzerland and possible specific obstacles when relocating to this country. Then, we present four case-studies on different competences and attitudes that are valued as important in the job-search process, in the specific context of Switzerland with an eye on future moves. We conclude by exploring the implications of this study and future avenues of research on skills in migration.

\section{Conceptual framework: Validating Skills Across Time and Space}

We understand skills as going beyond formal qualifications. What Baláž and Williams (2004) call "total human capital" includes a broad set of competences with an emphasis on individual social 
biographies in a particular context. Existing literature on international validation and transfer of skills focuses on a "human capital" perspective, which understands knowledge, skills, and other competences that are relevant to economic activity (Hartog, 1999; Lulle et al., 2019). Indeed, the literature links human capital to other forms of capital (social, cultural, symbolic and financial) and shows how they all together evolve together evolve through migration and may even increase develop migrants' capacity to move. Here we do not focus on the economic value of individuals' human capital but on migrants' "skills". In line with Yeoh and Huang (2011), we challenge the dichotomy between economic and social spheres in the definition of skills. Skills can also acquire meaning from a person's everyday life and play a role in the way a person self-identifies and transforms oneself in the workplace (Urciuoli, 2008), as well as actively engages with a specific context vis-à-vis other people (e.g., other family members). In particular, we draw upon the definition of skills offered by Ingold, according to which skills are "subjective, context-dependent, practical 'knowledge how'" (Ingold, 2001, p. 21), inseparable from human subjectivity, people's personal experience and their embeddedness in a socio-cultural context:

"skill, in short, is a property not of the individual human body as a biophysical entity, a thing-in-itself, but of the total field of relations constituted by the presence of the organism-person, indissolubly body and mind, in a richly structured environment" (Ingold, 2001, p. 21)

The focus here is not on how specific countries, like the country of origin versus the destination country, "influence possibilities of effective validation of migrant knowledge abroad" (Nowicka, 2014, 172), but rather on how different places simultaneously enter into the narrative of migrants, 
on how these individuals make sense of, use, and transform their skills on the move while also considering future possible destinations. It is not only a matter of places that count in the subjective definition, validation, and mobilization of skills (although they constitute important structural constraints or opportunities) but also, we suggest, the kind of social relationships that constitute a specific migratory experience for these people and the role of others (for example family members or employers). Migrants also build new networks and mobilise social connections in search of personal objectives, in our case to improve chances of employability (Schapendonk, 2018).

Skills, in the migrants' narratives, can hence represent situated "practical knowledge" (Ingold, 2000, p. 316), through which individuals value personal abilities and competences, and make sense of themselves and their professional life in a specific context. As a result, workers, from being mere "bundles of skills" (Urciuoli, 2008), are also capable to learn and mobilise alternative skills that will give them value in the local labour market and help them expand their own opportunities (Cangià et al., 2019). In this regard, Nowicka (2014) suggests moving

\footnotetext{
"from understanding skilled migrants as people with a particular type of education and occupation to considering migrants as agents capable of developing new skills upon arrival in a host country.” (p.172)
}

Personal and professional, past and present "skills" intertwine with each other when mobile and highly skilled people perceive surrounding opportunities and obstacles and engage with the local environment. 
Following a temporal approach to migration and mobility (Griffith, Rogers \& Anderson, 2013), we also explore how people use skills while constructing their migration trajectories and making sense of time changes, by referring to past experiences and transforming skills in the present, in view of an unknown future. Griffith, Rogers and Anderson (2013) have proposed the consideration of various times and temporalities at stake in the experience of migration, such as: people's biographies, becoming and multiple transformations resulting from spatial movement; the experience of synchronicity and disjuncture relating to migration; the multiple tempos and rhythms characterizing movement; as well as people's orientations to time (to past and to the future) when on the move. The subjective validation of skills in migration can also be explored with regard to time and temporality, more specifically in the way people experience time, and move between past, present and future to construct their work and life trajectories. The validation of skills in this sense becomes a future-oriented "knowledge practice" (Adam \& Groves, 2007), a practice of construction of knowledge about oneself across time, through which a person can "render the uncertain more certain, the insecure more secure, and the unknowable more knowable" (Adam \& Groves, 2007, p. 6).

In a similar vein, a focus on migration trajectories sees international migration as a dynamic process with strong transformative dimensions which requires continuous adjustments and navigations (Schapendonk et al., 2018). Migration, as a process of movement through time and space, has a profound effect on how people define themselves in the present and how they imagine their future possible selves. A focus on migration trajectories allows for a broader understanding of skills' valuations, by including combinations of skills gained at different stages of life, such as multiple, multidirectional and circular migration patterns (Lulle et al., 2019; Moret, 2017). Such 
a non-linear perspective puts an emphasis on the processes that expose embodied efforts, emotional labour and interdependencies (Schapendonk \& Steel, 2014). In line with these studies, we look at the evolvements, redirections and continuous adjustments of our interviewees, and observe how moving in time and space has influenced their aspirations and perspectives.

\section{The Study: Highly Skilled Migrants in Switzerland}

Increasingly research recognises that highly skilled migrants ${ }^{2}$ also face challenges of moving and living across international borders, and questions the images of highly skilled mobile people as "free-moving elites" (Favell et al., 2006, p. 8) living in a frictionless world (Cangià \& Zittoun, 2018; Yeoh \& Huang, 2011). Recent research in particular, points to the diversity among highly skilled migrants in terms of their professional and legal status (e.g., asylum-seeking), duration of stay and their experiences in the receiving local contexts (Conradson \& Latham, 2007; Meier, 2014; Mozetič, 2018). The different vulnerabilities that highly skilled migrants (including highly skilled refugees) can face within economic and social spheres, puts into question the dichotomy between 'voluntary' and 'forced' migration, between highly skilled migrants moving out of free choice and without any constraints, and other migrants who migrate due to economic and political reasons. A variety of challenges also arise for highly skilled migrants, who, as mentioned above, are all but a homogeneous group. Entering the job markets at matching skill levels, positioning oneself within a new working life, but also maintaining relationships and organizing family life are just some of the challenges of transnational lives (Aure, 2013; Conradson \& Latham, 2005; Geddie, 2012; Ho, 2011b; Ryan \& Mulholland, 2014). By exploring the case of accompanying

\footnotetext{
${ }^{2}$ For the purpose of this paper, we use the term "highly skilled migrants" as those who have completed tertiary education and have moved internationally.
} 
partners and refugees, those with the "middling status position" (Conradson \& Latham, 2005) who often moved without a prearranged job, our research shows that experiences of geographical mobility as 'highly skilled' may also disempower people or make them re-interpret their skills (Ariss \& Syed, 2011).

The case of Switzerland is very interesting regarding the specific example of highly skilled migrants. 41 percent of all migrants of working age are highly educated, a fact that contrasts strongly with the situation of many other European countries known for low levels of education among migrants (only 22.6 percent of migrants have higher education in Germany and the EUwide average is 29.4 percent) (OECD/European Union, 2018). It is also one of the OECD countries with the fastest increase in number of highly educated migrants (OECD/European Union, 2018, p. 67). With high R\&D spending ${ }^{3}$ and hosting many headquarters of multinational enterprises, Switzerland is a global center for business and research making it an attractive environment for a highly skilled workforce. The study by KPM Engineering actually ranked Switzerland as the best country for attracting and retaining high-skilled workers (Desjardins, 2019). Immigration to Switzerland is highly selective and to a large extent temporary, which reflects the current demands on the Swiss labour market as well as the skill-selective immigration policy. Over two thirds of migrants living in Switzerland come from EU/EFTA countries, with the largest flows coming from neighboring countries like Italy, Germany and France (Swiss Office for Migration, 2018). The dual admission system, which allows for free movement of citizens of EU/EFTA Member States and limits the admission of Third-country nationals, contributes to such filtering of newcomers

\footnotetext{
${ }^{3}$ Switzerland came eight in a worldwide ranking of R\&D expenditure as share of gross domestic product in 2019 (IRI, 2019).
} 
(Sandoz, 2018). Third-country nationals can only enter Switzerland on permits as reunified family members, asylum seekers, students, or as "qualified workers" who are "absolutely needed" (Swiss Federal Council, 2002). Residence permits are issued for all migrants and mostly for the purpose of work (47 percent), followed by family reunification (31 percent) and education (11 percent) (NCCR-on the move, 2019). As such, a majority of migrants already have a job offer on their arrival to Switzerland (NCCR-on the move, 2016). But for those coming to the country without a pre-arranged job contract, finding work is not straightforward. Figures for unemployment are significantly higher for foreigners compared to Swiss nationals (7.9 percent vs. 3.1 percent) (FSO, 2018).

Irrespective of their skill level, highly skilled migrants are more often unemployed or working in jobs below their education level compared to their native counterparts. Over-education is common among these migrants. Data from the Swiss Federal Statistical Office shows that 19.9 percent of first-generation migrants with tertiary education are educated beyond what is necessary for their occupational position in 2017. This share was only 9.7 percent of those without a migration background (Swiss Federal Statistical Office, 2018). Female migrants are in particular affected by overeducation (23.8 percent among the first generation of migrant women and 10.3 percent among Swiss women without a migration background) (Swiss Federal Statistical Office, 2018). The mismatch between migrants' education and local labour market needs, difficulties in the recognition of qualifications, discrimination in the hiring process, legal status, and lack of information and support are some of the most often mentioned reasons for migrants not being able to find work at their level of qualifications (Berthoud, 2012; Hercog \& Sandoz, 2018a; OECD/European Union, 2015; Pecoraro, 2011; Riaño, 2003; Riaño \& Baghdadi, 2007; Riaño \& 
Wastl-Walter, 2006). Recent research on highly skilled migration in Switzerland has shown that different 'migration channels' (family-, company-, study- or protection-oriented channel) can shape the ways skills are used, and that access to new labour markets depends on much more than only on people's skills (Sandoz, 2018). Movements through different migration channels are associated with different legal pathways and organizational support for migrants, which in turn can have an impact on migrants' ability to make use of their skills in a host country. By including a diverse group in the study on highly skilled migration, we will show that 'privileged' situations of smooth integration in terms of job success exist predominantly for people with a pre-arranged job, either through an international intercompany transfer or by self-initiated expatriation (Sandoz, 2018).

The results discussed in this article are drawn from data collected from 2015 to 2018 in the context of two research projects on "highly skilled migrants", mobile professional workers and their families living in Switzerland ${ }^{4}$. Both projects include biographical and in-depth interviews with a variety of individuals who have completed tertiary education and were looking for a job at their level of expertise. In particular, we draw upon 25 interviews conducted with people who have recently moved to Switzerland mainly as family members $(n=21)$ and in some cases also as students (2) or asylum seekers (2), even though these categories are not necessarily so clear cut. The interviews were conducted in the French- and the German-speaking part of Switzerland, primarily in the Geneva Lake Region and Basel area, both known for high immigration rates. Respondents include people from different backgrounds, nationalities, legal statuses and migration trajectories. They have completed at least a bachelor's degree. At the time of the interviews, they

\footnotetext{
${ }^{4}$ These projects were conducted in the context of the National Center of Competence in Research NCCR - On the Move, and funded by the Swiss National Science Foundation (SNSF)
} 
were looking for employment or just started a new job after being unemployed shortly before. We are specifically interested in the period of job searching and in exploring how migrants re-assess their professional identity during this phase.

We also attended numerous initiatives organised by local organizations focusing on the job search. This way, we learned about different strategies and experiences of job searching as well as used it as a channel to reach our potential respondents. In addition, we used our personal networks to contact people who were going through a longer period of job search. Interviews were inspired by a reflexive and ethnographic approach (Ellis, 2003; Hockey \& Forsey, 2012), an approach that is particularly appropriate for understanding social phenomena from a more reflexive point of view. Through this approach, during the interview, the researcher can actively participate in the narration of the person's life, and share personal information. This helped evoke narration from the part of the participant, so as to better explore the subjective dimension of the issue under exploration. Respondents were asked about their migratory trajectory, their everyday life, social networks, work situation and future plans. They were asked specifically about the job-search process and how they felt about it. On some occasions, participants were explicitly asked if they had ever thought about developing an alternative profession and job profile as a way out of current unemployment. This provided a starting point for discussing the way they personally understood what counts as their own competences, capabilities, and interests and the use they thought they could make of these concretely.

A diverse sample of interviewees provides a useful basis for exploring the different ways skills are valued in the process of job search in a new country. At the same time, it requires careful 
consideration of the many factors influencing how people make sense of their trajectories. We analyzed the interviews transversally through a combined thematic, content and interpretative analysis (Geertz, 1977). Here we illustrate four individual case studies as representative of wider patterns and variations of skills' subjective validation to enter the Swiss labour market. We observe how our interviewees looked for employment, reinvented a new professional profile, or simply engaged with the locality during the job-searching period. In the next section, we discuss our results through the presentations of interviewees' experiences.

\section{What counts as 'skill' on the move}

What counts as 'skill' in highly skilled migration is more than professional expertise and qualification, especially in those specific situations where different constraints challenge the validation of recognised qualifications and professional expertise. It can change in a new environment or in a different moment of one's life trajectory. This is particularly present for those migrating for reasons other than work, as they are often forced to search for jobs in a particular place, might have different family obligations, and might face some barriers relating to their migrant status (e.g., legal status or discrimination) (Liversage, 2009; Purayastha, 2005). As such, the personal understanding of skills and of "being skilled", and the opportunities and practices to validate skills go together with the specificity of the social and personal identity of the individual in that particular moment and place (e.g., the role as an accompanying partner after previously having been a professional), and are affected by distinct structural constraints. 
Legal status, language barriers, insufficient childcare arrangements, as well as lack of relevant social networks, specificities in the Swiss labour market and preference for local candidates were some of the common constraints that our respondents encountered. They were often surprised by how "closed" the Swiss job market is, even for qualified professionals (Cangià, 2018). Several respondents expressed their initial expectations that there will be plenty of opportunities for them within the international organizations or multinational companies and that not speaking a local language will not pose an obstacle within the English-speaking workplace. In general, however, the job-searching period lasted longer than expected. Even when individuals held permits that allowed them to work (which is mainly the case for accompanying partners in Switzerland), they were not receiving responses from potential employers or were rejected on the grounds that they lacked local work experience. Our analysis suggests that social networks were crucial for gathering specific knowledge of the local labour market and for gaining access to potential employers. Even organizations supporting job searches encouraged people to use any chance to expand their social networks and use them as a means of increasing their chances to find employment.

Gender also plays a role in this context, in particular gendered norms and social expectations that can create a form of pressure for those people who invested in their professional career before the move. Accompanying partners, who often live in a relationship where both partners negotiate their work trajectories in order to continue their careers in migration, for example, often need to confront with gendered norms relating to a male breadwinner role (Cangià et al., 2019), or with stereotyped images of the "housewife" (Cangià, 2017). Some people, however, can interpret the temporary experience of migration as a socially acceptable reason to stop working, in the form of investment 
in family care, as well as alternative and personal interests (Suter \& Cangià, 2020; Yeoh \& Willis, 2005).

Facilitating factors in the validation of skills can include personal abilities, such as selfreinvention, self-exploration, and finally imagination. A personal history, a past experience or alternative abilities that were not considered as relevant before, can become essential in order to respond to the specificities and novelty of the surrounding environment. Likewise, other skills become less relevant in a new location or in a different geopolitical environment. Some of the skills mobilised by our respondents in their search for employment and when engaging with the locality go beyond the mere expertise in their own professional sector. These come to include abilities and knowledge based on past experiences, cultural and personal resources (e.g., language skills), attitudes (e.g., social skills) and perceived expertise acquired through the experience of migration (Kaufmann et al., 2004; Moret, 2017). Respondents tend to refer to specific aspects in their trajectories that become relevant particularly in the context of Switzerland and through the temporal experience of migrating often across different countries. These aspects include people's ethnic background and nationality, previous work and past experiences, personal resources and social attitudes developed as a result of years of international mobility or life in Switzerland. The narratives of Joseph, Victor, Katerina and Una ${ }^{5}$ are illustrative of how different aspects of one's own personal life and/or past professional experience can become 'skills' when reinventing oneself in a new context, as well as when making sense of time and the future.

\section{Joseph: knowledge from countries of origin}

\footnotetext{
5 All names are pseudonyms.
} 
Having origins from and a sense of belonging to a particular country can be valued as professional competence, like in the case of Joseph. Joseph grew up in Eritrea, and after living in several other European countries, he moved to Switzerland in 2014 to join his future wife. She had only recently obtained refugee status and was therefore not allowed to live outside of Switzerland. He obtained a $\mathrm{PhD}$ in law and worked in a couple of research positions across different European universities. Once in Switzerland, he worked in short-term positions but faced many challenges to get a residence permit. He missed opportunities due to unresolved residency status and the reluctance of potential employers to go through the difficult admissions procedures for Third-country workers. He tried to find a job on his own to get a residence permit based on work and simultaneously used the channel of family reunification to join his wife. When describing his work experience in Switzerland, he explained how he had a chance to use his knowledge and expertise as a legal adviser with a focus on his country of origin and on the experience of migration. He provided expert legal opinions about the political situation in Eritrea and was asked to verify the accuracy of the information in the asylum process. At the same time, he worked as a consultant for a European NGO, also dealing with issues of migration from Africa. Through his engagement as a political activist pushing for change in his home country, he is connected with several networks and gets invited to participate in different projects as an expert.

Using this expertise, Joseph believes that he can create his future working life in Switzerland. Despite the legal obstacles to enter the labour market in Switzerland, he used different opportunities to work with human rights organizations in Geneva. As the main seat of the United Nations in Europe, Geneva is an important place in terms of his advocacy work on human rights 
and international law. He sees many opportunities for professionally establishing himself in Geneva as his professional background in human rights, as well as his knowledge of the situation in his home country, are sought after by Swiss and international institutions. Even though he struggled with obtaining residency status, he was confident in his abilities to establish himself in Geneva. One option for him would also be to establish his own NGO to support the integration of Eritrean migrants in Switzerland, which has become increasingly relevant due to recent political developments. His ethnic background and accompanying linguistic and culturally-specific competences are instrumental for such an endeavor in the future. He imagines what would be the best context in which his project could take form:

With a hundred per cent confidence I can establish my own NGO in Geneva. I can tell you that. Because I see a number of areas and opportunities. Integration for example is one hot issue. Integration not only a Swiss concern. Throughout Europe, migration issues are becoming a very, very topical issue. And in that context, these newly arriving refugees have to be well integrated into the societies. Because if they are not integrated, they will end up establishing their own subculture. Their own subcommunities. And you know this is going to be from ten, fifteen, twenty years from now. This is going to be one of the major sources of conflicts in Europe. (Joseph)

The example of Joseph shows how individuals can re-make sense of and shape their skills to take advantage of job opportunities in a specific place. Origins and ethnic background can become a resource to build a new job profile. In his pursuit to enter the professional market in Geneva, Joseph stresses his knowledge based on his personal life in Eritrea and his activist networks just as much 
as formal legal education. Some of these skills might have been "unexpected resources" (Bertaux, 2003) resulting from current geopolitical developments in Switzerland (Liversage, 2009). With high numbers of Eritreans applying for asylum in Switzerland, and with a more restrictive Swiss reception policy, the knowledge about the Eritrean situation became an asset for Joseph.

With other examples in our sample who also found jobs in migrant integration projects, or considered becoming language instructors of their mother tongues, we see how migrants may actively validate their skills by "drawing on their immigrant identity" (Liversage, 2009), using their ethnic belonging as a resource or cultural capital in different fields (Erel, 2010; Nowicka, 2014). Joseph maintains his self-understanding as a highly-skilled professional by drawing on his cultural background and imaging himself as a "cultural broker" (Diken, 1998) or a mediator for his less-skilled co-ethnics.

\section{Victor: a combination of past personal and working life}

Another example shows how individual biographies are combined with professional profiles to adapt to the new environment and labour market. Victor is in his early $40 \mathrm{~s}$ and moved to Switzerland in 2014 to follow his wife working for a multinational corporation. After two years spent at home taking care of their small child, Victor recently managed to find temporary employment with the same company where his wife works. He works as a consultant, providing the company with a very specific profile he could create based on his past professional experience in community development and agriculture in developing countries, his volunteering job with an NGO during his unemployment in Switzerland, his past life working internationally, as well as his 
family background. Victor tells how he could manage to use his own previous work experience to create a new profile for the company. During the interview, he talks about how he 'reinvented himself' in the new environment. When asked to elaborate on this 'self-reinvention', Victor explains how he came up with the idea of the consultancy and how he negotiated with the employer a mix between his skills and their needs:

I have a totally new focus which is very firmly rooted in agriculture, and that's been-I can do this because of my experience with volunteering work [...] and also that I originally come from a rural community. My family, I've had family members who were farmers and involved in the food business, and butchers, and bakers, and so it's I suppose bringing in some of the new things that I've learnt and connecting that with some of my family background, so to be able to convince [the company] that I've skills that they need and they listened, and it's working well. (Victor)

The mobilization of certain skills here is a clear example of how "practical knowledge" can be developed to access opportunities not only in the context of the Swiss labour market (where the company is located physically), but also the international context where the company works. His international knowledge in Africa, his previous work experience, a volunteering job in Switzerland, as well as his family history, all together, create a (transnational) skill set that helps Victor to invent a new professional profile. Working as a consultant suits his family situation as his wife's career takes precedence at the moment and he has taken up more family responsibilities. When asked about how he feels concerning this combination of competences that made this new consultancy job possible, Victors shows enthusiasm about change and about the risk he took in 
doing something new in Switzerland, 'a global piece of work', as he calls it, which makes him travel around the world and create a network transnationally. This current work, Victor explains, also allows him to consider future moves (like moving to Africa) with his family, by taking into account both his wife's and his career path. In this sense, the validation of skills comes to work as a temporal "knowledge practice" (Adam \& Groves, 2007), through which Victor attempts to construct knowledge about himself based on the past and in orientation to the future. The case of Victor also demonstrates how skills are not innate or acquired, but can be shaped through practice and creativity, and through the field of relations that a person constitutes across time through their embeddedness in the material environments (Ingold, 2000).

\section{Katerina: social attitudes and interpersonal skills}

There is a clear agreement among respondents on how social and interpersonal competences matter for improving labour market prospects. Not only do respondents reflect on practical experiences coming from their social world, but they also use certain interpersonal characteristics as influencing their networking skills. Katerina, who benefitted from generous relocation support as she joined her partner working for a multinational company, saw her driven and outgoing character as most important for her job search as well as for her social relations.

Katerina, a medical doctor from Greece, who has previously worked in the pharmaceutical industry, describes herself as being proactive and industrious, characteristics that helped her during the settling-in period in Switzerland. She was offered extensive support from her husband's employer so she would be able to enter the labour market as soon as possible. She acknowledges 
this offer as important also for its social dimension that put her in the position to meet other people and become socially active in a new place. This support was significant, yet she explicitly acknowledges how personal character played a role. She explains:

So basically, that was the support, which was the most important at least when you come to Basel because my husband started to work immediately and so I stayed, so now what? I had like an activity going and meeting someone, talking to someone and connected me with others. And I am telling you that this depends also on the character because, maybe the other person receives the same help but she's more reserved and it takes time. For me, it didn't take so much because I started exploring the city and then I start doing my connections on my own. Because I am like this. (Katerina)

She joined several professional and social networks to make sense of her job searching time, to share experiences, and to boost her confidence. She had previously lived in other countries and speaks several languages, but she did not see these experiences relevant in her new place in Switzerland. As she was not able to speak German and felt frustrated with job searching, she was ready to leave just before she was finally offered a job. The period of looking for work lasted a year and a half and she found it very hard. What she describes as her personal character, helped her get through by being constantly active and doing something valuable by attending courses and meetings. Finally, when she was offered a job as an international medical manager, the profile of the job matched her multilingual background and previous experience of living in Latin America. Her example again shows how besides formally recognised skills and expertise in a specific professional sector, the knowledge based on past experiences and specific personal characteristics 
becomes a practical "knowledge how" (Ingold, 2000, p. 316) that a person can employ in order to engage with the environment as well as to plan future moves. The experience of Katerina also shows the role played by emotional skills and emotion work (Hochschild, 1979), in particular by the ability of a person to adapt one's emotional response to a specific context and situation in order to act upon the external circumstances. These skills help Katerina respond to the social implications and normative expectations of migration, such as not only finding new employment, but also adapting to a new social and cultural context and establish new relationships.

In addition, Katerina's as well as Victor's case show how the role of hiring organizations is crucial also for accompanying partners (Shinozaki, 2014, p. 538). Connections through partners who were employed at multinational companies substantially helped to expand networks and to find employment in a number of other cases, which proves that the role of employers goes beyond just offering relocation support.

\section{Una: 'mobility capital' for a new job profile}

As expressed in the notion of lifelong learning (Beckett, 2000, p. 41), individuals draw on experience, knowledge and abilities from all areas of their lives. "Knowledge is learned and accumulated through personal and social life experiences...being shaped by both personal inner factors and outside environmental factors" (Yang, 2003, p. 108). This is the case as we consider the large use of skills relating to language knowledge acquired by living across different countries, or the kind of consultancies that people develop based on their international experience in specific contexts - both geographical and professional. The capacity to move hence can become a form of 
capital (Kaufmann et al., 2004), "mobility capital" or "international capital" that the experience of living across different countries can provide to migrants in search of social mobility (Moret, 2017; Wagner \& Réau, 2015) . This is the case of Una, a woman in her forties following her husband who works as a civil servant. After years of maternity leave and unemployment, when she could not find a job in Switzerland, she decided to search for employment in another EU country, where she recently started working as head of the international policy unit at a University. The family still lives in Switzerland and she commutes internationally on a weekly basis. Una explains how she used her past experience as an accompanying partner, mixed with volunteering job experience in a spousal association in Switzerland and professional expertise in the evaluation of labour market programs, in order to create a new professional profile. When asked how she feels about her new job, she explains:

Yeah. I like it very much. I'm very happy with it, also quite relieved that being abroad for so many years didn't have such an extreme impact on my career as I thought but it is like you said, I've been changing subjects all the time. [...] Still making a career though, so I'm very happy with that. This kind of fits from both sides because the university is trying to internationalise, so I'm the right person to come in because I can carry the internationalization strategy. I can tell them what it means to go abroad internationally, to expand, so there's a lot of the culture awareness is there, so I bring a lot of aspects that I learned during the ten years into a leading position at the university now. So that's very nice to do. (Una) 
Una reconstructs her migratory trajectory across time, and makes sense of this through the lens of professional expertise and competences acquired throughout years of migration. In her years of job searching in two different countries she had to deal with many job coaches and recruiters, which she can now put into practice on the recruitment side. In her new position as a manager, she also has to hire people and considers the skills she acquired through her job searching and volunteering at the spousal association as very helpful. Only through her personal experience of moving twice with her family, she was able to validate and combine skills that supported in obtaining a desired position: "At the end it all fits together", she says.

With her new occupation, she manages to use her experiences of international mobility and transmit these to the local population that might want to become internationally mobile. Her international experience was acquired through years of adapting to new environments and learning from migration infrastructure supporting her and her family. Una's experiences as a migrant and as an accompanying partner are valued both by herself and by her new employer and become skills that she can concretely use to get out of unemployment and find her own new way back to the labour market. Her case shows how past experiences of migration, future opportunities of geographical mobility, as well as the capacity to be mobile as a commuter across countries, can work as 'mobility capital' (Moret, 2017), and be useful to establish a professional life across transnational borders and across time. Una's case also shows how migrants' origins and previous destinations of migration are just as important for skills validation as the place of destination (Nowicka 2014). Being on the move as an accompanying partner and living in different countries, including the country of origin, helped Una shape a new career profile and trajectory. 


\section{Conclusion}

This paper contributes to understanding skills in migration by considering the diverse ways in which skills are validated and made sense of by people themselves. While our findings corroborate the importance of personal social networks (Ho, 2011a; Kõu \& Bailey, 2014) and migration infrastructure (Lin et al., 2017; Sandoz, 2018), the narratives presented highlight further implications for understanding skills as connected to multiple locations and times. Place as an analytical dimension is not understood only in terms of Switzerland's skilled labour market, but we also look at how skills were dynamically defined in different sociocultural environments, from countries of origin and previous countries of migration to receiving context and future destinations. Similarly, migrants' past experiences and future plans play an important role in defining which aspects of their skills will be acted upon in the process of skill mobilization. Migration often

presents a rupture in people's life course, which creates the need or an opportunity for reassessing their professional identity by tapping into the past and the future.

Firstly, we proposed a perspective on skills in migration based on people's experiences, in order to show the importance of personal aspects in both the social and economic spheres of people's lives in times of unemployment and work uncertainty. While the profession can be the main anchor of identity for highly skilled migrants (Colic-Peisker, 2010) and the workplace can become an important context of local incorporation (Hercog \& Tejada, 2013; van Riemsdijk, 2014), this is different for those migrants who moved without a pre-arranged job. When faced with difficulties to validate their professional competences, they can emphasise the skills acquired in their previous positions, reinterpret them on the basis of the surrounding environment and relations, and link 
them with their personal life and aspirations. Formation of a skill set becomes then both practical knowledge and actual knowledge practice to make sense of life and career across space and time.

These reflections brought us to a redefinition of the broader concept of 'skills' with a focus on different life dimensions, such as family and personal life. People are creative in terms of mobilising alternative abilities and knowledge, or in terms of presenting their skills in different ways when they see that their professional expertise is not validated in the specific context of work. The findings confirm that we need a transnational and temporal framework for understanding skills' validation and mobilization (Nowicka, 2014). Knowledge about their home countries, or other places they have lived in, past experiences as a migrant, volunteering experiences, and family history can turn into an asset for reinventing oneself in a new context. Social skills and personal attitudes are also useful to expand networks and enhance opportunities, or to simply engage with others in a similar situation.

The second analytical contribution of this paper is the temporal dimension of skill validation in migration (Griffiths et al., 2013). We discussed the mobilization of skills as a temporal practice that individuals can engage in to construct knowledge about themselves, to make sense of change, to "tame" the uncertainty of future, to create a new professional profile, as well as to imagine and plan the next destination of migration. All respondents from the presented case studies have lived in several countries before moving to Switzerland, which is common among highly-skilled migrants. We considered people's references to personal expertise and skills for reinterpreting the past, making sense of the present, and "controlling" the future in the context of a mobile life. People utilise a variety of elements in this regard. As discussed through our case-studies, these can 
include: past professional skills, which can be reimagined for future work; personal interests, reused for personal development and a new (mobile) working life; past experience as a migrant supporting in the making of a new working life; and finally, personal and emotional attitudes, which can help a person make sense of time and deal with change. Their future is not fixed to Switzerland. Many of our respondents plan to move to other places in the (un)defined future, either because of their partner's positions or because of other family plans. Difficulties with validating their skills and finding employment is an important reason to start imagining their opportunities elsewhere. While we do not wish to disregard the number of people who would like to settle down in Switzerland, it is equally important to also point out the large share of undecided people and those who are certain about moving elsewhere. They will likely focus on skills which can be mobilised and valued also in future locations.

Often in a condition of simultaneity between different places (van Riemsdijk, 2014) and between the past and the future, people's subjective understanding of skills draws from different life dimensions in multiple locations and is constantly changing. Further research is needed on the temporal dimension of migration with special regard to skills (Griffiths et al., 2013), and the role of imagination in various experiences of mobility to working life (Cangià \& Zittoun, 2020; Salazar, 2011). A temporal perspective on skills in migration, more specifically, can contribute to understanding how the value and meanings associated with skills are not static, but change through time, in particular for those who face different rules of labour market as a result of their migratory experience. Focusing on the experience of mobility helps us move away from looking at migrants as somehow exceptional and we rather point to how skills are experienced when searching for new employment in a new environment. What did not count as skill before can be reevaluated and 
imagined given the new conditions of the surrounding environment and of (often imagined) future destinations of one's migratory trajectory. In this assemblage of different elements, with different amplifying or constraining connections between them, involving previous, current and future geographical and temporal locations, individuals create a new transnational skill set. 


\section{References}

Adam, B., \& Groves, C. (2007). Future Matters: Action, Knowledge, Ethics. BRILL.

Ariss, A. A., \& Syed, J. (2011). Capital Mobilization of Skilled Migrants: A Relational Perspective. British Journal of Management, 22(2), 286-304. https://doi.org/10.1111/j.1467-8551.2010.00734.x

Aure, M. (2013). Highly skilled dependent migrants entering the labour market: Gender and place in skill transfer. Geoforum, 45, 275-284. https://doi.org/10.1016/j.geoforum.2012.11.015

Baláž, V., \& Williams, A. M. (2004). 'Been there, done that': International student migration and human capital transfers from the UK to Slovakia. Population, Space and Place, 10(3), 217-237. https://doi.org/10.1002/psp.316

Bauder, H. (2003). "Brain Abuse”, or the Devaluation of Immigrant Labour in Canada. Antipode, 35(4), 699-717. https://doi.org/10.1046/j.1467-8330.2003.00346.x

Beaverstock, J., \& Boardwell, J. (2000). Negotiating globalization, transnational corporations and global city financial centres in transient migration studies. Applied Geography, 20(3), 277-304.

Beckett, D. (2000). Making workplace learning explicit: An epistemology of practice for the whole person. Westminster Studies in Education, 23, 41-53.

Bertaux, D. (2003). The usefulness of life stories for a realist and meaningful sociology. In R. Humphrey, R. Miller, \& E. Zdravomyslova (Eds.), Biographical research in Eastern Europe: Altered Lives and Broken Biographies (pp. 63-97). Ashgate.

Berthoud, C. (2012). Dequalifiziert! Das ungenutzte Wissen von Migrantinnen und Migranten in der Schweiz. Swiss Red Cross. 
Bjerregaard, T. (2014). Engaging institutions in global careers: Highly skilled self-initiated expatriates' journeys through a Nordic welfare state. European Management Journal, 32(6), 903-915. https://doi.org/10.1016/j.emj.2014.04.003

Burrell, K. (2010). Staying, returning, working and living: Key themes in current academic research undertaken in the UK on migration movements from Eastern Europe. Social Identities, 16(3), 297-308. https://doi.org/10.1080/13504630.2010.482401

Cangià, F. (2017). (Im)Mobility and the emotional lives of expat spouses. Emotion, Space and Society, 25, 22-28. https://doi.org/10.1016/j.emospa.2017.10.001

Cangià, F. (2018). Precarity, Imagination and the Mobile Life of the "Trailing Spouse." Ethos, $46(1), 8-26$.

Cangià, F., \& Zittoun, T. (Eds.). (2018). Editorial: “When 'Expatriation' is a Matter of Family. Opportunities, Barriers and Intimacies in International Mobility.” Migration Letters, 15(1), 1-16.

Cangià, F., \& Zittoun, T. (2020). Editorial Special Issue: Exploring the Interplay between (Im)mobility and Imagination. Culture \& Psychology.

Cangià, F., Zittoun, T., \& Levitan, D. (2019). Work and Geographical Mobility: The Case of the Male Accompanying Spouses. In P. Bendassoli (Ed.), Culture, work and psychology: Invitations to dialogue (Information Age Publishing, Vol. 3, pp. 159-182).

Cederberg, M. (2017). Social class and international migration: Female migrants' narratives of social mobility and social status. Migration Studies, 5(2), 149-167. https://doi.org/10.1093/migration/mnw026 
Colic-Peisker, V. (2010). Free Floating in the Cosmopolis? Identity-Belonging of Transnational Knowledge Workers. Global Networks, 10, 467-488. https://doi.org/10.1111/j.14710374.2010.00298.x

Conradson, D., \& Latham, A. (2005). Transnational urbanism: Attending to everyday practices and mobilities. Journal of Ethnic and Migration Studies, 31(2), 227-233. https://doi.org/10.1080/1369183042000339891

Conradson, D., \& Latham, A. (2007). The Affective Possibilities of London: Antipodean Transnationals and the Overseas Experience. Mobilities, 2(2), 231-254. https://doi.org/10.1080/17450100701381573

Dahinden, J. (2010). The dynamics of migrants' transnational formations: Between mobility and locality. In R. Bauböck \& T. Faist (Eds.), Diaspora and Transnationalism: Concepts, Theories and Methods (pp. 51-72). Amsterdam University Press.

Desjardins, J. (2019, March 20). Which countries are best at attracting high-skilled workers? World Economic Forum. https://www.weforum.org/agenda/2019/03/which-countries-areset-to-attract-the-highest-skilled-workers-from-abroad/

Diken, B. (1998). Strangers, Ambivalence and Social Theory. Ashgate.

Dustmann, C., \& Frattini, T. (2013). Immigration: The European experience. In D. Card \& S. Raphael (Eds.), Immigration, Poverty, and Socioeconomic Inequality. Russel Sage Foundation.

Ellis, C. (2003). The Ethnographic I: A Methodological Novel about Autoethnography. AltaMira Press.

Erel, U. (2010). Migrating Cultural Capital: Bourdieu in Migration Studies. Sociology, 44(4), $642-660$. 
Favell, A., Feldblum, M., \& Smith, M. P. (2006). The Human Face of Global Mobility: A Research Agenda. In M. P. Smith \& A. Favell (Eds.), The Human Face of Global Mobility: International Highly Skilled Migration in Europe, North America and the AsiaPacific. Transaction Publishers.

Föbker, S., Imani, D., Nipper, J., Otto, M., \& Pfaffenbach, C. (2016). Translocal Life and Integration of Highly-skilled Migrants in Germany. Erdkunde, 70(2), 109-124.

Friberg, J. H., \& Midtbøen, A. H. (2017). Ethnicity as skill: Immigrant employment hierarchies in Norwegian low-wage labour markets. Journal of Ethnic and Migration Studies, 1-16. https://doi.org/10.1080/1369183X.2017.1388160

FSO. (2018). Statistical Data on Switzerland 2018. Federal Statistical Office.

Geddie, K. (2012). The Transnational Ties that Bind: Relationship Considerations for Graduating International Science and Engineering Research Students. Population, Space and Place, 19(2), 196-208. https://doi.org/10.1002/psp.1751

Geertz, C. (1977). The Interpretation of Cultures (New edition). Basic Books.

Griffiths, M., Rogers, A., \& Anderson, B. (2013). Migration, Time and Temporalities: Review and Prospect. COMPAS Research Resources Paper, March 2013. Centre on Migration, Policy and Society Oxford.

Hartog, J. (1999). Behind the veil of human capital (OECD Observer, pp. 37-39). OECD.

Hercog, M., \& Sandoz, L. (2018a). Selecting the highly skilled: Norms and practices of the Swiss admission system for non-EU immigrants. Migration Letters, 15(4), 503-515. https://doi.org/10.33182/ml.v15i4.2 
Hercog, M., \& Sandoz, L. (2018b). Highly Skilled or Highly Wanted Migrants?

Conceptualizations, Policy Designs and Implementations of High-skilled Migration Policies. Migration Letters, 15(4), 453-460. https://doi.org/10.33182/ml.v15i4.534

Hercog, M., \& Tejada, G. (2013). Incorporation of skilled migrants in a host country: Insights from the study of skilled Indians in Switzerland. IMDS Project Working Papers Series, WP 58, 1-15.

Ho, E. L.-E. (2011a). Migration trajectories of "Highly Skilled" middling transnationals: Singaporean transmigrants in London. Population, Space and Place, 17, 116-129.

Ho, E. L.-E. (2011b). Identity Politics and Cultural Asymmetries: Singaporean Transmigrants 'Fashioning' Cosmopolitanism. Journal of Ethnic and Migration Studies, 37(5), 729746. https://doi.org/10.1080/1369183X.2011.559715

Hochschild, A. R. (1979). Emotion Work, Feeling Rules, and Social Structure. American Journal of Sociology, 85(3), 551-575.

Hockey, J., \& Forsey, M. (2012). Ethnography is not Participant Observation: Reflections on the Interview as Participatory Qualititative Research. In The Interview: An Ethnographic Approach (Jonathan Skinner, pp. 69-88). Berg.

Ingold, T. (2000). The Perception of the Environment (Reissue edition). Routledge.

Ingold, T. (2001). Beyond art and technology: The anthropology of skill. In M. B. Schiffer (Ed.), Anthropological Perspectives on Technology (pp. 17-29). https://abdn.pure.elsevier.com/en/publications/beyond-art-and-technology-theanthropology-of-skill

IRI. (2019). 2019 Global R\&D Funding Forecast. IRI. 
Kaufmann, V., Bergman, M. M., \& Joye, D. (2004). Motility: Mobility as capital. International Journal of Urban and Regional Research, 28(4), 745-756. https://doi.org/10.1111/j.0309-1317.2004.00549.x

Kõu, A., \& Bailey, A. (2014). 'Movement is a constant feature in my life': Contextualising migration processes of highly skilled Indians. Geoforum, 52, 113-122. https://doi.org/10.1016/j.geoforum.2014.01.002

Ledin, A., Bornmann, L., Gannon, F., \& Wallon, G. (2007). A persistent problem. Traditional gender roles hold back female scientists. EMBO Reports, 8(11), 982-987. https://doi.org/10.1038/sj.embor.7401109

Lin, W., Lindquist, J., Xiang, B., \& Yeoh, B. S. A. (2017). Migration infrastructures and the production of migrant mobilities. Mobilities, 12(2), 167-174. https://doi.org/10.1080/17450101.2017.1292770

Liversage, A. (2009). Finding a Path: Investigating the Labour Market Trajectories of HighSkilled Immigrants in Denmark. Journal of Ethnic and Migration Studies, 35(2), 203226. https://doi.org/10.1080/13691830802586195

Lulle, A., Janta, H., \& Emilsson, H. (2019). Introduction to the Special Issue: European youth migration: Human capital outcomes, skills and competences. Journal of Ethnic and Migration Studies. https://doi.org/10.1080/1369183X.2019.1679407

Massey, D. (2005). For Space (1 edizione). Sage Pubns Ltd.

McDowell, L. (2009). Working Bodies: Interactive Service Employment and Workplace Identities. Wiley-Blackwell.

Meier, L. (2014). Migrant Professionals in the City: Local Encounters, Identities, and Inequalities. Routledge. 
Moret, J. (2017). Mobility capital: Somali migrants' trajectories of (im)mobilities and the negotiation of social inequalities across borders. Geoforum. https://doi.org/10.1016/j.geoforum.2017.12.002

Mozetič, K. (2018). Being Highly Skilled and a Refugee: Self-Perceptions of Non-European Physicians in Sweden. Refugee Survey Quarterly, 37(2), 231-251. https://doi.org/10.1093/rsq/hdy001

NCCR-on the move. (2016). Migration-Mobility Survey 2016. National Center of Competence in Research - on the move.

NCCR-on the move. (2019). Migration-Mobility Indicators. National Center of Competence in Research -on the move. https://indicators.nccr-onthemove.ch/for-what-administrativereason-are-migrants-admitted-in-switzerland/

Nowicka, M. (2014). Migrating skills, skilled migrants and migration skills: The influence of contexts on the validation of migrants' skills. Migration Letters, 11(2), 171-186.

Nowotny, K. (2016). Are overqualified migrants self-selected? Journal of Human Capital, 10(3), $303-346$.

OECD/European Union. (2015). Indicators of Immigrant Integration2015: Settling In. OECD.

OECD/European Union. (2018). Settling in 2018: Indicators of immigrant integration. OECD/EU. https://doi.org/10.1787/9789264307216-en

Pecoraro, M. (2011). Gender, Brain Waste and Job-Education Mismatch among Migrant Workers in Switzerland. International Migration Paper, 111. http://dx.doi.org/10.2139/ssrn.2294436 
Plöger, J., \& Becker, A. (2015). Social Networks and Local Incorporation-Grounding Highskilled Migrants in Two German Cities. Journal of Ethnic and Migration Studies, 41(10), 1517-1535. https://doi.org/10.1080/1369183X.2015.1015407

Purayastha, B. (2005). Skilled migration and cumulative disadvantage: The case of highly qualified Asian Indian immigrant women in the US. Geoforum, 36(2), 181-196.

Raghuram, P. (2004). The difference that skills make: Gender, family migration strategies and regulated labour markets. Journal of Ethnic and Migration Studies, 30(2), 303-321.

Riaño, Y. (2003). Migration of skilled Latin American women to Switzerland and their struggle for integration. In Y. Mutsuo (Ed.), Latin American Emigration: Interregional Comparison among North America, Europe and Japan (pp. 313-343). Japan Centre for Area Studies, National Museum of Ethnoglogy (Osaka).

Riaño, Y., \& Baghdadi, N. (2007). Understanding the Labour Market Participation of Skilled Immigrant Women in Switzerland: The Interplay of Class, Ethnicity, and Gender. Journal of International Migration and Integration / Revue de l'integration et de La Migration Internationale, 8(2), 163. https://doi.org/10.1007/s12134-007-0012-1

Riaño, Y., \& Wastl-Walter, D. (2006). Immigration policies, state discourse on foreigners and the politics of identity in Switzerland. Environment and Planning, 38, 1693-1713.

Rigby, M., \& Sanchis, E. (2006). The concept of skills and its social construction. European Journal of Vocational Training, 37(1), 22-33.

Ryan, L., \& Mulholland, J. (2014). Trading Places: French Highly Skilled Migrants Negotiating Mobility and Emplacement In London. Journal of Ethnic and Migration Studies, 40(4), 584-600. https://doi.org/10.1080/1369183X.2013.787514 
Salazar, N. B. (2011). The Power of Imagination in Transnational Mobilities. Identities, 18(6), 576-598. https://doi.org/10.1080/1070289X.2011.672859

Sandoz, L. (2018). Understanding access to the labour market through migration channels. Journal of Ethnic and Migration Studies, 1-20. https://doi.org/10.1080/1369183X.2018.1502657

Schapendonk, J. (2018). Navigating the migration industry: Migrants moving through an African-European web of facilitation/control. Journal of Ethnic and Migration Studies, 44(4), 663-679. https://doi.org/10.1080/1369183X.2017.1315522

Schapendonk, J., \& Steel, G. (2014). Joris Schapendonk \& Griet Steel (2014) Following Migrant Trajectories: The Im/Mobility of Sub-Saharan Africans en Route to the European Union, Annals of the Association of American Geographers, 104:2, 262-270, DOI:

10.1080/00045608.2013.862135. Annals of the Association of American Geographers, 104(2), 262-270. https://doi.org/10.1080/00045608.2013.862135

Schapendonk, J., van Liempt, I., Schwarz, I., \& Steel, G. (2018). Re-routing Migration Geographies: Migrants, Trajectories and Mobility Regimes. Geoforum. https://doi.org/10.1016/j.geoforum.2018.06.007

Shinozaki, K. (2014). Career Strategies and Spatial Mobility among Skilled Migrants in Germany: The Role of Gender in the Work-Family Interaction. Tijdschrift Voor Economische En Sociale Geografie, 105(5), 526-541. https://doi.org/10.1111/tesg.12111

Suter, B., \& Cangià, F. (2020). Time and Family On the Move: 'Accompanying Partners’ in Geographical Mobility. Time \& Society.

Swiss Federal Council. (2002). Message concernant la loi sur les étrangers, FF 2002 3469. (FF 2002 3469) (No. 3469). https://www.admin.ch/opc/fr/federal-gazette/2002/3469.pdf. 
Swiss Federal Statistical Office. (2018). Anteil der Angestellten mit Tertiärausbildung, die einen Beruf ausüben, für den eine solche Ausbildung nicht notwendig ist, nach Migrationsstatus, verschiedenen soziodemografischen Merkmalen und Grossregionen. https://www.bfs.admin.ch/bfs/de/home/statistiken/bevoelkerung/migrationintegration/integrationindikatoren/alleindikatoren/arbeitsmarkt/ueberqualifikation.assetdetail.6352095.html

Swiss Office for Migration. (2018). Ausländerstatistik 3. Quartal 2018: Zuwanderung aus EU/EFTA nimmt weiter ab. SEM. https://www.sem.admin.ch/sem/de/home/aktuell/news/2018/2018-10-26.html Tissot, F. (2016). Highly-Skilled Labour Migration in Switzerland: Household Strategies and Professional Careers (No. 10; Working Paper Series "Gender, Diversity and Migration"). Urciuoli, B. (2008). Skills and selves in the new workplace. American Ethnologist, 35(2), 211228. https://doi.org/10.1111/j.1548-1425.2008.00031.x

van den Broek, D., Harvey, W., \& Groutsis, D. (2015). Commercial migration intermediaries and the segmentation of skilled migrant employment. Work, Employment and Society, 30(3), 523-534. https://doi.org/10.1177/0950017015594969

van Riemsdijk, M. (2014). International Migration and Local Emplacement: Everyday PlaceMaking Practices of Skilled Migrants in Oslo, Norway. Environment and Planning A: Economy and Space, 46(4), 963-979. https://doi.org/10.1068/a46234

Wagner, A.-C., \& Réau, B. (2015). Le capital international: Un outil d'analyse de la reconfiguration des rapports de domination. In J. Siméant (Ed.), Guide de l'enquête globale en sciences sociales (pp. 33-46). CNRS éditions. 
Waters, J. L. (2009). Transnational geographies of academic distinction: The role of social capital in the recognition and evaluation of 'overseas' credentials. Globalisation, Societies and Education, 7(2), 113-129. https://doi.org/10.1080/14767720902907895

Yang, B. (2003). Toward a holistic theory of knowledge and adult learning. Human Resource Development Review, 2, 106-129.

Yeoh, B. S. A., \& Huang, S. (2011). Introduction: Fluidity and Friction in Talent Migration. Journal of Ethnic and Migration Studies, 37(5), 681-690. https://doi.org/10.1080/1369183X.2011.559710

Yeoh, B. S. A., \& Willis, K. (2005). Singaporeans in China: Transnational women elites and the negotiation of gendered identities. Geoforum, 36, 211-222. 